\title{
Deprivation, Frustration and Aggression: An interrogation of Fulani Herdsmen Terror in Nigeria.
}

\author{
'Lanre Olu-Adeyemi \\ Department of Political Science and Public Administration, \\ Adekunle Ajasin University \\ Akungba-Akoko, Ondo state, Nigeria.
}

\begin{abstract}
The Fulani Herdsmen has been ranked as the fourth deadliest terrorist group in the world by the 2014 Global terrorism Index. This paper examines the activities of the Fulani Herdsmen against the background of their persistent violent attacks on farms, farmers and communities across Nigeria to the detriment of national unity and security. Relying on the theory of Deprivation, Frustration and Aggression; the paper relies on the strength of secondary (including historical) and to some extent, primary sources of data to situate the Fulani Herdsmen Terror as the nexus of the deprivations emanating from the plethora of social, economic, environmental and political situations in Nigeria. The paper makes recommendations on ways to bring the terror attacks under control.
\end{abstract}

Keywords: Fulani Herdsmen, Terrorism, National Unity.

\section{INTRODUCTION}

Each year, the Global Terrorism Index (GTI), which is published by Sidney, Australia-based Institute for Economics and Peace reveals a list of the world's most deadly terrorist organizations. In 2013, Nigeria's Fulani herdsmen did not rank among the top five groups, having been the cause of only 63 deaths throughout the year (Punch Editorial, May 6, 2016). The following year, however, the militants were responsible for 1,229 deaths, which placed them at number four on the list, outdone by only the Taliban, the Islamic State, and Boko Haram (Institute for Economics and Peace, 2016). Since then, the Fulani militants have continued to cause death and destruction in Nigeria. In the first quarter of 2016, Fulani militants were responsible for nearly 500 deaths, and have showed no signs of slowing down. Despite the havoc that has been wrought by this group, the Fulani are largely ignored in discussions of world terror, and if mentioned are overshadowed by Nigeria's second terror group, Boko Haram (Punch Editorial, May 6, 2016). This may not be the case for much longer, as the Fulani herdsmen terror is emerging an uncontrollable threat to the very fabrics of the Nigerian body polity.

Nigeria is a multi-ethnic country that has consistently battled the contradictions involved in keeping diverse peoples, cultures and values together. Nigeria, as a country, came into existence in 1914 with the British amalgamation of the erstwhile autonomous empires, kingdoms and city states. These political entities had nothing in common other than trade and wars of expansion. Nigeria has a history of ethnicity that is so varied to an extent that there is no definition of a Nigerian beyond that of someone who lives within the borders of the country. Despite this multiplicity of ethnic groups, economic factors result in the significant mobility of Nigerians of multiple ethnic and religious backgrounds to reside in territories in Nigeria that are outside their ethnic or religious background, resulting in the intermixing of the various ethnic and religious groups. 
According to Olugbenga (2017):

Although inter-ethnic cohabitation occurs in many places in Nigeria, each of the Eastern, Western and Northern Nigeria is dominated by the Igbo, Yoruba and Hausa-Fulani ethnic groups, respectively. While the average Igbo is known for business, the Yoruba are mainly arable and cash crop farmers but also engage in serious academic pursuits. Conversely, the average Hausa-Fulani is a herdsman who is easily identified with cattle and general livestock tending, an endeavour that takes him to different parts of the country in search of lush vegetation for animal pasture, particularly southern Nigeria which receives more rainfall than the north. Thus, many Hausa/Fulani are pastoralists who herd cattle and other livestock, often on an itinerant basis.

Interestingly, the relationship between Nigeria's myriad ethnic groups is witnessing an increased spate of hate actions that have now taken over the hitherto existing cordial and fruitful relationships. In fact, concerning the Herdsmen and their host communities across Nigeria, studies have shown that the usual camaraderie, good fellowship, warm acceptance, mutual respect and tolerance that used to be the situation has gradually changed over time to explosive situations of disrespect, mutual suspicion, and resources induced conflicts, destruction of properties, violence, killing and terror (Seddon and Sumberg, 1997; Gbaka, 2014).

These undeniable changes in relationship have been induced mainly by urbanization, desertification, and the indifference of the Nigerian government. There is increased struggle for arable land and water between farmers who need it for cultivation and herdsmen that needs it for grazing. In the process, conflicts break out between the farmer who labour to cultivate the land and the herdsmen who bring their cattle to eat up crops and contaminate community watering-places. However in recent years, the spate of conflicts between herdsmen and farmers have taken a new dimension in frequency and dimension as the Herdsmen now terrorise farmers and farming communities with guns and ammunitions which have always led to the wanton destruction of communities, killing, maiming and raping of daughters and mothers. The Fulani herdsmen, a predominantly Muslim group, have no green lands, and green grasses for their cattle. Thus, they chose to fight, kill and take over farm lands through violence. While our government looked the other way. Herdsmen have metamorphosed from arrow and machete carrying people to sophisticated gun wielding people in just a few years.

\section{THE FULANI HISTORICALLY}

Fula or Fulani or Fulbe are an ethnic group of people spread over many countries, predominantly in West Africa, but found also in Central Africa and The Sudan of East Africa. The countries in Africa where they are present include Mauritania, Senegal, Guinea, The Gambia, Mali, Nigeria, Sierra Leone, Benin, Burkina Faso, Guinea Bissau, Cameroon, Côte d'Ivoire (Ivory Coast), Niger, Togo, the Central African Republic, Ghana, Liberia, and as far as Sudan in the east.

The Fulani are traditionally a nomadic, pastoralist, trading people, herding cattle, goats and sheep across the vast dry hinterlands of their domain. The Fulani were the first group of people in West Africa to convert to Islam through jihads, or holy wars, and were able to take over much of West Africa and establish themselves not only as a religious group but also as a political and economic force. Over $99 \%$ of Fulani are Muslims. It is said that to be a Fulani is to be a Muslim. They are the missionaries of Islam and continued to conquer much of West Africa. Their lives revolved around and were dedicated to their herds. Today, some estimate as many as 18 million Fulani people stretch across the countries of West Africa. They remain to be the 
largest group of nomadic people in the world, earning them the appellation of "Fulani herdsmen." The current struggle between the Fulani and other peoples of Nigeria represents the end result of years of conflict between the Fulani and others in the area and results from many social, economic, and environmental factors that have long affected the Fulani.

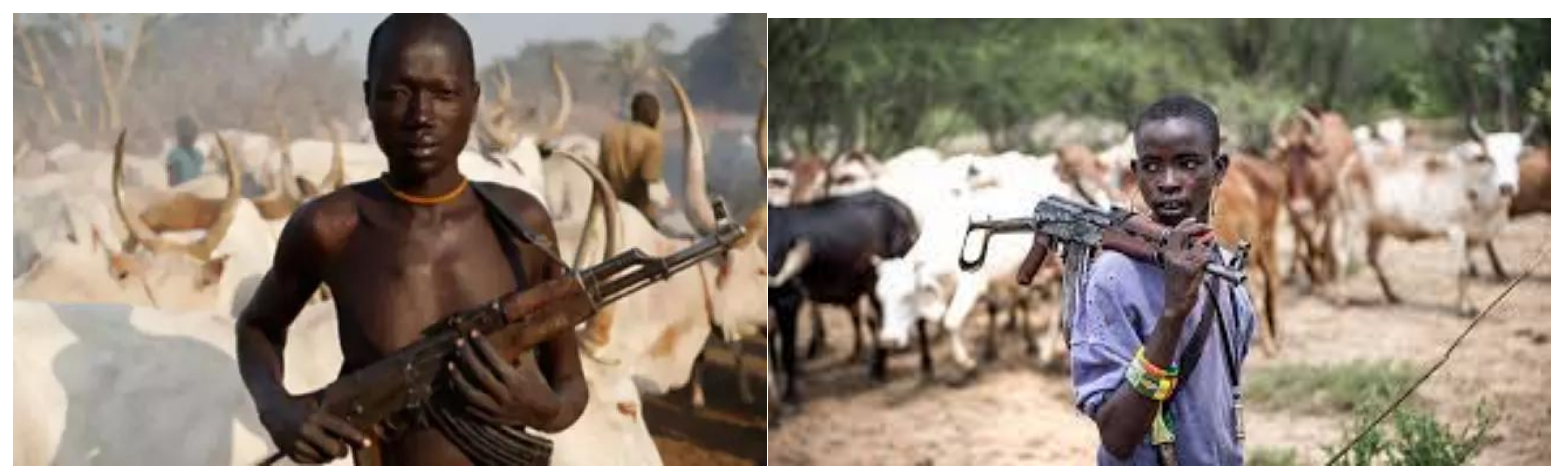

Fulani Herdsmen with Gun
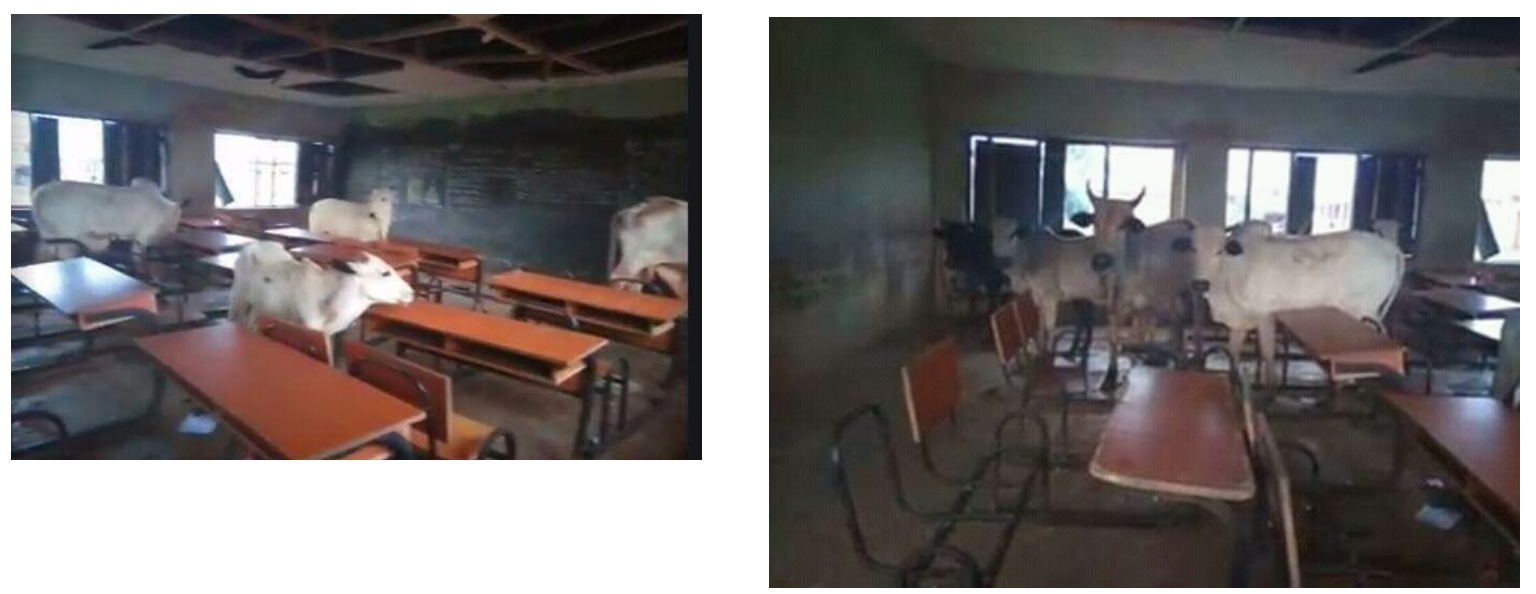

This is Ohonvbe Model Primary School, Ikpoba, Okha LGA, Edo State. The Fulani herdsmen did not only take the cows to the school field but also inside the class rooms to chase out the pupils on June 9, 2017.

Never before, however, have Fulani resorted to such widespread terrorist activity. In fact, between 2010 and 2013, only 80 people were killed by Fulani herdsmen compared to more than 1,200 killed in 2014 alone, an escalation for which many factors have been credited. The Nigerian government has not addressed Fulani concerns, and many Fulani have been forced to leave their lands in recent years by deforestation, causing them to become unfamiliar with permissible grazing lands, angering local communities.

\section{Theory Of Deprivation, Frustration And Aggression}

A plethora of literature exists on the menace of Fulani Herdsmen in Nigeria under different analytical frameworks. Some of these works have employed frameworks such as climate change, relative deprivation and processual theories of conflict (Olaniyan, Francis and OkekeUzodike, 2015); ecopolitics (Blench, 2003), eco-violence (Okoli and Atelhe, 2014), and global climate change (Okoli, Enyinnia, Elijah and Okoli, 2014; Odoh and Chigozie, 2012, Abbass, 2012), Olugbenga (2017) among others. The present study differs from the above mentioned that sought to discuss the carnage committed by the herdsmen because it aims at explaining terrorism induced by a combination of deprivation, frustration and aggression. 
Fundamentally, the relative deprivation theory is a view of social change and movements, according to which people take action for social change in order to acquire something (for example, opportunities, status, or wealth) that others possess and which they believe they should have, too.

Dollard, Millard, et al. (1939) while espousing the theory, posited that frustration leads men to act aggressively, thus, taking a cue from the above, this paper's main argument is that the frustration experienced by the Fulani Herdsmen on the one hand and the farmers/communities that have been attacked on the other hand, is caused by relative deprivation, and the resulting aggression is manifested as Fulani Herdsmen terror as currently witnessed.

Ted Gurr (2010) in his highly reputed book - Why Men Rebel, espoused the nexus of frustration and aggression as well as the place of deprivation is a classic book that explores why people engage in violence. Though written long before the current rash of insurgencies in our world, it has a lot to say about what is happening in the Fulani Herdsmen Terror on Nigerians. In this book, Gurr examines the psychological frustration-aggression theory which argues that the primary source of the human capacity for violence is the frustration-aggression mechanism. Frustration does not necessarily lead to violence, Gurr says, but when it is sufficiently prolonged and sharply felt, it often does result in anger and eventually violence. Gurr explains this hypothesis with his term "relative deprivation," which is the discrepancy between what people think they deserve, and what they actually think they can get. If, however, there is a significant discrepancy between what they think they deserve and what they think they will get, there is a likelihood of rebellion. Gurr posits this to be the case even if there is no question that their basic needs will be met. The first situation may be a desperate one, but it is the second that is frustrating. And, according to Gurr (2010), just as frustration produces aggressive behavior on the part of an individual, so too does relative deprivation predict collective violence by social groups.

A number of other variables influence the use of violence as well, for example the culture, the society, and the political environment. The culture must at least accept, if not approve, violent action as a means to an end. Violence is also more likely if the current leadership and/or the socio-economic/political system is seen as unresponsive. Another factor is whether violence is considered to be a viable remedy to the problem.

Dougherty and Pfaitzgraff (1971) also espoused the theory of deprivation, frustration and aggression. To the duo, the theory is anchored on the premise that aggression is always a function of frustration and the occurrences of aggressive behaviour always presuppose the existence of frustration. The central theme of the theory is that scarcity is the product of insufficient supply (impact of climate population explosion) or unequal distribution of resource as a result of deprivation which ultimately leads to aggression. Operating from this assumption, it can be argued that conflicts do not just occur; rather there must be a reason for such conflict. For instance, depletion of natural resource can lead to competition for scarce resources and this competition can also lead to deprivation of the weak and vulnerable access to these resources. On the issue of frustration, it means that one's access to means of livelihood (farming or grazing as the case may be) is being thwarted by another or possibly by particular circumstances and that one's reaction to this thwarting is that of annoyance.

To comprehend this assumed connection between frustration and relative deprivation, we must look at Gurr's definitions. Relative deprivation "is defined as actors' perception of discrepancy between their value expectations and their value capabilities". It is the gap between that "to which people believe they are rightfully entitled" and that which "they think 
they are capable of getting and keeping". It is essential to note that deprivation is not based on wants or needs alone, but on the wants and needs that we feel we ought to have or deserve.

More often than not, the Herdsmen are frustrated due to desertification, thus, the reality is that they face forced migration and as they migrate, series of challenges are encountered which in turn brings frustration. Similarly, farmers who have struggled to cultivate farmlands also get frustrated whenever herds of cattle destroy their farmlands. The Fulani Herdsmen terror is a struggle over values and claims to scarce resources in which their aims are to neutralize, injure or to eliminate the host communities in a bid to fend for their animals.

The violent activities of the Fulani Herdsmen occurs because of the accumulation of residual instigatory effects of frustration. The terrorist activities of the herdsmen is traceable to the desertification that has caused depletion in grazing opportunities or scarcity of feed for their animals which in the long-run affects their economic wellbeing. If a herdsmen losses his flock to drought and water scarcity, he may be frustrated because of the loss of livelihood. From this reality, he may be aggressive and since, he cannot channel it to the natural causes, he may in the long-run channel it to any person or group that obstructs his migration to a safe area. The more disturbing issue about the Herdsmen is that they also block the highways with their cattle, rob and kidnap people, keep them captives in the bush and demand for ransom. The Herdsmen have also been involved in the rape of old and young women and burning of communities (The Vanguard, 2015).

Similarly, the farmers and host communities of the Middle Belt and Southern Nigeria also gets frustrated whenever animals trample on their farmlands to eat up their cultivations. The reality too is that they become aggressive and channel their aggression to the herdsmen and their cows. After all, no rational being or farmer can stand idle and watch his means of livelihood being destroyed by herdsmen cattle. As a result of this reality, conflict and confrontation is bound to occur. The main thrust of the conflict is the loss of the means of livelihood. As has been noted earlier, within the middle-belt region and across Southern Nigeria, terror caused by the Fulani intrusion into their land has remained unresolved.

\section{Fulani Herdsmen Terror in Nigeria}

The tension between Fulani herdsmen and the farming communities has been in existence for several years but has escalated in recent times to include attacks, kidnappings and killings by the nomads. A cursory statistics reveals that between 2007 and 2012 the herdsmen slaughtered in different parts of Nigeria people totaling about 100, but between 2013 and 2015 the human carnage perpetrated by the Fulani nomads in different parts of Nigeria has risen to figure totaling about 1012. The state that seems to be the hardest hit by this bestial acts of killings by the herdsmen are Benue, Taraba, Nassarawa, Plateau, Kaduna, Kastina and Enugu with pockets of such attacks across most of the states in southern Nigeria. The disturbing issue is that although in the past, these Fulani herdsmen who wander in the bushes grazing their cattle do unleash terror on the host communities; the magnitude of damages to life and properties was not high as it is becoming now. The fact also is that in the past they operate with knives, clubs, bow and arrows but now they move with sophisticated arms - gun, riffles, Ak-47, pump action and the likes. Worse still, they deploy their sophisticated weapons and attack their target communities at a time that they are most vulnerable such as at midnight or on Sundays when they are in church, killing people indiscriminately, burning houses and looting properties.

Most worrisome is the brutality and impunity with which these herdsmen operate with no regard for the law and the sanctity of human life. Painfully still the Nigeria police, military and 
other statutory security agencies came to no useful help and the unsuspecting villagers are mercilessly slaughtered in their homes with their houses and properties destroyed. According to Olugbenga (2017), most attacks by herdsmen occur in non-Hausa dominated states (Fulani herdsmen are itinerant, migrant people who move about in search of pasture and water for their flocks), particularly in the middle belt and southern states. Most of the dead are from other ethnic groups and the material loses are colossal, which aptly justifies the description of Fulani herdsmen as terrorists.

All terrorist organisations the world over are known as movements that uses terror as a weapon to achieve their goals often times done through intimidation or coercion or by instilling fear as presently witnessed in the activities of Fulani Herdsmen in Nigeria.

Unfortunately, the central government seem unperturbed as no concerted efforts have been made to quell the Fulani Herdsmen terror. From Agatu in Benue State, Akure in Ondo State, Bukuru area in Plateau State, Oke Ogun area in Oyo State, Gassaka and Bali local government areas in Taraba State to Nimbo in Enugu State, rampaging Fulani herdsmen seem to be on a mission to draw blood. And blood they are getting.

Sadly, as it was the case at the onset of Boko Haram insurgency, the dastardly acts of Fulani herdsmen have not been accorded the requisite handling by appropriate authorities. For instance, it took President Buhari something akin to ages before he eventually came out with a position on the appalling activities of the Fulani herdsmen. The motive behind such costly silence, in the face of acts capable of disintegrating the country, remains a mystery to ordinary Nigerians. It is exactly the same pattern of belated response that gave Boko Haram the necessary impetus that turned it into such a monstrous group in the country. The reason(s) why our leaders often wait pointlessly for the blood of hapless compatriots to be spilled in needless circumstances before stemming the tide would continue to be a mystery. This brings us to the thorny issue of modus operandi of both Boko Haram and Fulani herdsmen. The method of operation of the two groups is quite curious. As for Boko Haram, since it has now assumed the status of a global terrorist body, the sophisticated nature of their arsenal and operation is no longer unusual. What is, however, odd is the kind of riffles being reportedly used by rampaging Fulani herdsmen across the country. It becomes curious as to what Fulani herdsmen could be doing with such combat-purposed assault rifles. What could be the source of such dangerous ammunition? If there is, indeed, a source, then, like Boko Haram, there would definitely be sponsors. If there are sponsors, the next puzzle is: what could be their motives? Could it be that purported skirmishes by Fulani herdsmen across the country are just clever ploys by some 'evil genius' to further throw the country into prolonged chaos? Could it be that recent upsurge in Fulani herdsmen atrocities is being orchestrated by some 'powerful' people with sinister intent to derail the country?

Everywhere the herdsmen go, sorrow, tears and blood trail them. Curiously, they operate in such audacious fashion that makes mockery of our national security arrangement. Government action has not been forthcoming against the Fulani militants, and bills intended to resolve issues in the middle belt have been highly contested in the Nigerian legislature. The Nigerian President Muhammadu Buhari has also been accused of giving the Fulani preferential treatment due to his own Fulani heritage, and legislation proposed by his party to provide grazing land for the Fulani herdsmen has been met with suspicion and outrage. Despite the efforts of some isolated State governments to make laws to curb the excesses of the herdsmen, the Fulani Herdsmen terror is on the rise in Nigeria thus bringing to question whether other things motivate the Fulani Herdsmen terror and what must be done to foster peace, unity, understanding and tolerance among Nigeria's myriad ethnic groups. 
It is instructive to know that the apparent inability of the federal government to regulate indiscriminate cattle grazing is inextricably linked to the political economy of cattle rearing in Nigeria. First, President Muhammadu Buhari is a Fulani and the Grand Patron of the Miyetti Allah Cattle Breeders' Association of Nigeria (MACBAN), the umbrella body for cattle rearers in the country. The fact that the president himself is a Fulani major cattle dealer could be responsible for his seeming inability to separate the responsibilities of his office as president from his ethnic and economic interests as Fulani, cattle dealer and grand patron of MACBAN, thus, constraining him to call the rampaging Fulani herdsmen to order.

In the view of Olakiitan (2016), "the failure of government to address the situation decisively has several implications for Nigeria. The fact that herdsmen now carry sophisticated ammunition with which they kill and maim perceived opponents at will constitutes grave danger to national security. This is because security personnel including the police have not been able to withstand weapon-wielding herdsmen's boldness and firepower". The herdsmen have sacked whole communities, abducted elder statesmen, killed Police officers, raped, looted and perpetrated heinous crimes while the government has done nothing to arrest the situation (see timeline of Herdsmen Terror as reported in the Nigerian Media).

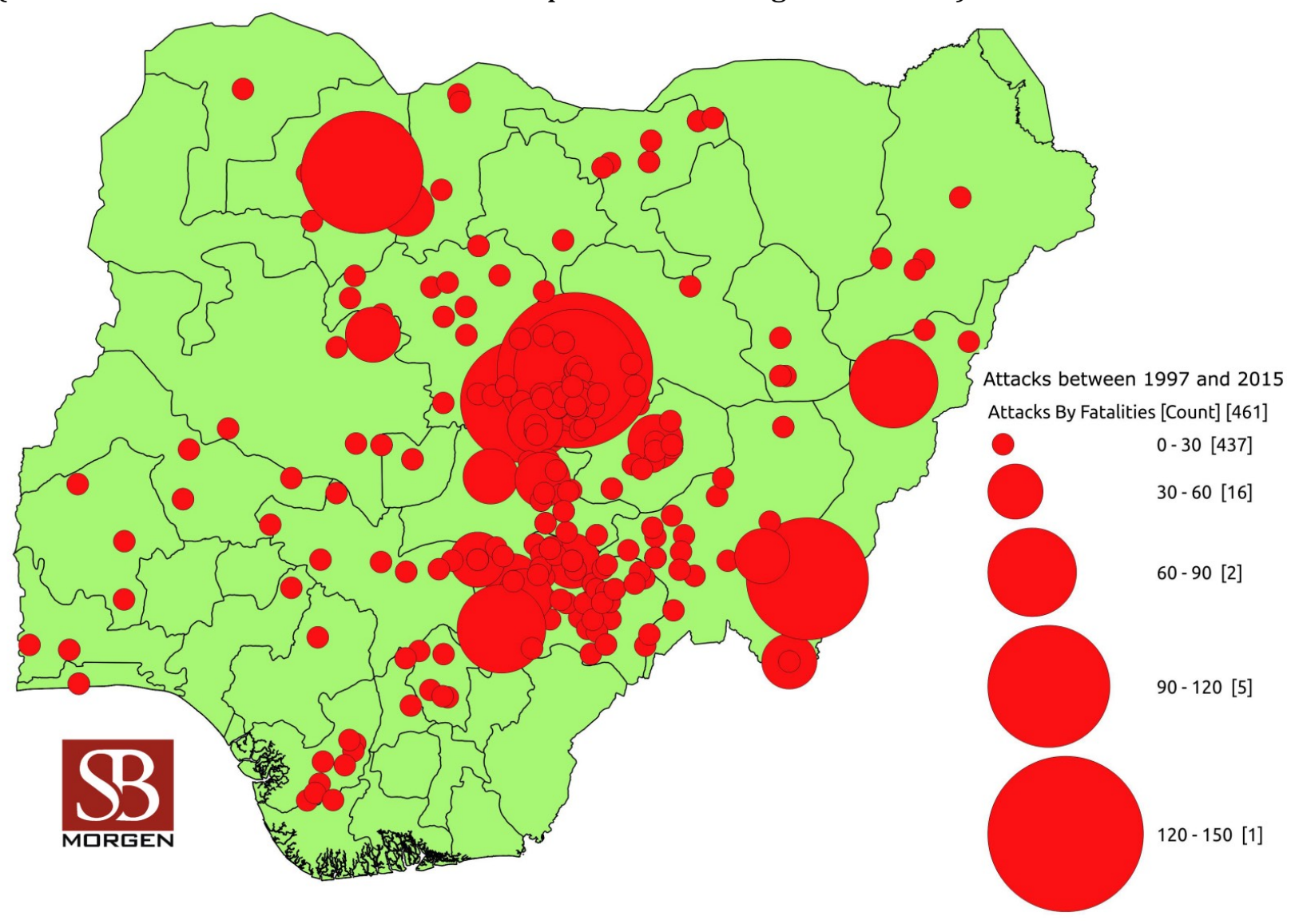

\section{The Way Forward}

Figure 1: Fulani Herdsmen Attack, 1997-2015

Given the consequences of the Fulani Herdsmen terror, the results of earlier researches on the subject matter and the revelations of this study, the following recommendations are made to checkmate the phenomenon:

First, state actors either out of economic, religious or ethnic considerations pretend as if the activities of the Fulani Herdsmen are not an act of terror! This is detrimental to national unity and security. Therefore, Government should take urgent measures to disarm these herdsmen, 
fish out and prosecute those involved, including their sponsors and bring them to justice. It will also be necessary to encourage and promote community policing and intelligence gathering to forestall grazing related terror.

Second, the growing complexities of the modern world coupled with environmental challenges no longer make nomadic grazing attractive. Government should therefore as a matter of urgency, consider and adopt a sedentary grazing policy/practice in the country.

Third, since resource scarcity has fuelled hate actions among ethnic groups in Nigeria, it would be necessary to initiate, support and sustain dialogue between herdsmen, villagers, traditional and community leaders and security agencies in order to nip checkmate the Fulani herdsmen terrorism.

Fourth, there is need to provide logistical support to security agencies to apprehend perpetrators of attacks.

Finally, the Federal Government must as a matter of urgency demonstrate fairness and commitment to citizen welfare no matter the tribe that is concerned. This will enhance national unity and security and also go a long way at remedying the scale of deprivation, frustration and aggression that is promoting ethnic hate action as presently witnessed in Nigeria.

\section{CONCLUSION}

The wave of Fulani herdsmen terror in Nigeria is alarming. It has damaged relations among Nigerian ethnic nationalities and poses a serious threat to the peaceful and continuous existence of Nigeria as a country due to the ethnic hate actions which it engenders as demonstrated in this paper. The Federal Government should expectedly wake up from its slumber and pretense to emplace policy frameworks to curb the menace in the overall interest of peace, unity and security in Nigeria's multi-ethnic and multi-religious set up.

\section{References}

Abbass, I.M. (2012): "No Retreat, No Surrender: Conflict for Survival between Fulani Pastoralists and Farmers in Northern Nigeria”, European Scientific Journal, Vol. 8, No.1, pp. 331-346.

Blench, R (2003): “The Transformation of Conflict between Pastoralists and Cultivators in Nigeria”, Cambridge, United Kingdom.

Dollard, J.D, Miller, N.E, Mowrer, O.H, and Sears, R.R (1939) Frustration and Aggression. New Haven: Yale University Freer

Dougherty, J.E and Pfaitzgraff, R.L (1971) Contending Theories of International Relations, Philadelphia: J.B Lippincott Company

Gbaka, E. (2014): “Managing conflict between Farmers and Pastoralists in Benue State, Nigeria”, Peace Trends, Issue 2 Vol.3., Centre for Sustainable Development and Education in Africa (October - December)

Gurr, T (2010) Why Men Rebel, Boulder: Paradigm Publishers

Institute for Economics and Peace (2016): Global Peace Index (GPI): 2016 Highlights, Sydney, Australia.

Odoh, S.I. and Chigozie, C.F. (2012): “Climate Change and Conflict in Nigeria: A Theoretical and Empirical Examination of the Worsening incidence of conflict between Fulani Herdsmen and Farmers in Northern Nigeria", Arabian Journal of Business Management Review, 2(1):110-124.

Olakiitan, V. (2016): “Oke Ako Fulani Herdsmen Invasion: Still Reeling from the Shock”, Thisdaylive, June 5.

Olaniyan, A., Francis, M. and Okeke-Uzodike, U. (2015): “The Cattle are “Ghanaians” but the Herders are Strangers: Farmer-Herder Conflicts, Expulsion Policy, and Pastoralist Question in Agogo, Ghana”, African Studies Quarterly, Vol.15, Issue 2 (March). 
Olugbenga, E.0 (2017) Peace by Pieces: The Politics of Herdsmen's Attacks, Grazing Policy and the Ekiti State Grazing Regulation Law, 2016, Advances in Social Sciences Research Journal, Vol. 4, No.5

Okoli, A.C. and Atelhe, G.A. (2014): "Nomads against Natives: A Political Ecology of Herder/Farmer conflicts in Nasarawa State, Nigeria", American International Journal of Contemporary Research, 4 (2): 76-88.

Okoli, I.C., Enyinnia, A.C., Elijah, A.G. and Okoli, C.G. (2014): “Cattle Management of Pastoralist and Conflict Resolution Strategies in the Tropical Humid Rain Forest Zone of Southern Nigeria”, Journal of International Scientific Publications: Agriculture and Food, 2:16-19.

Seddon, D. and Sumberg, J. (1997): “Conflict between Farmers and Herders in Africa: An Analysis”, Project R6618, SemiArid (Rangelands) Production System, Department for International Development (DFID) on behalf of the Livestock Production Programme, NR International.

The Vanguard (2015) Menace of Fulani herdsmen: Tales of woes from the East, October 3.

\section{Timeline Of Reported Deadly Encounters Between Fulani Herdsmen And Nigerians Nationwide (As Reported In The Media)}

1. Fulani herdsmen kill 7 again in Benue Published on March 26, 2014

http://www.pmnewsnigeria.com/2014/03/26/fulani-herdsmen-kill-7-again-in-benue/

2. Suspected Fulani herdsmen kill at least 23 in central Nigeria http://www.dailymail.co.uk/wires/afp/article3097701/Suspected-Fulani-herdsmen-kill-23-central-Nigeria.html 26 May 2015

3. Gov. Gabriel Suswam of Benue REPORTED that some Fulani herdsmen attacked Agatu Local Government Area of the state, leaving "high casualties including women and children"

http://www.vanguardngr.com/2013/05/many-killed-in-benue-herdsmen-attack-20-policemen-killed-innasarawa/ May 8th, 2013

4 Over 100 women, children and farmers killed in renewed Tiv/Fulani bloodbath http://www.vanguardngr.com/2013/05/over-100-women-children-and-farmers-killed-in-renewed-tivfulanibloodbath/

5. Fulani herdsmen sack Imo community http://sunnewsonline.com/new/national/fulani-herdsmen-sack-imocommunity/ April 23rd, 2013

6. 10 killed in Delta as villagers, herdsmen clash http://www.vanguardngr.com/2013/04/10-killed-in-delta-asvillagers-herdsmen-clash/ April 15th, 2013

7. Horror: Fulani herdsmen murder, rape and destroy Ohaji/Egbema community

http://www.hoohaaonline.co/horror-fulani-herdsmen-murder-rape-and-destroy-ohajiegbema-community/ April 15 th, 2013

8. Three killed, houses burnt as Fulani herdsmen attack Tiv farmers

http://www.vanguardngr.com/2013/04/three-killed-houses-burnt-as-fulani-herdsmen-attack-tiv-farmers/ April 9th, 2013

9. 5 killed in renewed Tiv/Fulani crisis http://www.sundaytrust.com.ng/index.php/news/12447-5-killed-inrenewed-tiv-fulani-crisis March 24th, 2013

10. 35 reported dead as Herdsmen Clash in Plateau State....March 21st, 2013 http://www.punchng.com/news/35villagers-killed-in-fresh-plateau-communal-clash/

11. Over 100 Beroms Killed By Fulani Militias - Lg Boss | 247 Nigeria http://247nigerianewsupdate.com/over100-beroms-killed-by-fulani-militias-lg-boss/ March 21st, 2013

12. Hundreds Flee As Clash Between Herdsmen And Community Kills 2 In Delta http://www.channelstv.com/home/2013/02/20/hundreds-flee-as-clash-between-herdsmen-and-communitykills-2-in-delta/ 21 Feb, 2013

13. 30 killed, scores injured in Fulani herdsmen, Eggon farmers clash http://www.vanguardngr.com/2013/02/30-killed-scores-injured-in-fulani-herdsmen-eggon-farmers-clash/ 08 Feb, 2013

14. Two die, thousands displaced as Fulani, Gwari clash in Abuja http://www.punchng.com/business/two-diethousands-displaced-as-fulani-gwari-clash-in-abuja/ Date Published 30 Dec, 2012

15. Save us from Fulani herdsmen, farmers plead http://t.co/B04L1pyI Date Published 02 Dec, 2012 
16. Plateau: Gunmen shoot 12 Fulani herdsmen, kill 12 cows http://tribune.com.ng/index.php/news/51231plateau-gunmen-shoot-12-fulani-herdsmen-kill-12-cows Date Published 21 Nov, 2012

17. Fulani Herdsmen Rapé Newlywed In Ogun http://www.informationnigeria.org/?p=36835 Date Published 21 Nov, 2012

18. Flash: 3 Dead As Hersdmen, Farmers Clash In Nasarawa http://t.co/PiAv6PZj Date Published 19 Oct, 2012

19. 30 feared dead in renewed Fulani/Tiv attack http://nigeriaindepth.com/30-feared-dead-in-renewedfulanitiv-attack/ Date Published 17 Oct, 2012

20. How I was almost killed by Fulani herdsmen - Motorcyclist http://t.co/Nsah6Duf Date Published 16 Oct, 2012

21. 2 killed in reprisal attack by Fulani in Plateau http://tribune.com.ng/index.php/front-page-news/46483-2killed-in-reprisal-attack-by-fulani-in-plateau Date Published 24 Aug, 2012

22. Fear grips Enugu community as Fulani herdsmen kill 2 teenagers http://dlvr.it/21P2yQ Date Published 18 Aug, 2012

23. Police arrests herdsmen with sub-machine guns

http://www.businessdayonline.com/NG/index.php/news/284-breaking-news/42272-police-arrests-herdsmenwith-sub-machine-guns DATE PUBLISHED: 03/08/2012

24. Suspected Fulani herdsmen kill serving senator, state legislator in Plateau http://www.punchng.com/news/suspected-fulani-herdsmen-kill-serving-senator-state-legislator-in-plateau/ Date Published 08 July, 2012

25. Fulani herdsmen attack 9 villages in Plateau state http://www.channelstv.com/home/2012/07/07/fulaniherdsmen-attack-9-villages-in-plateau-state/ Date Published 07 July, 2012

26. Oyo to prevent recurrence of Fulani herdsmen, farmers' clash

http://nationalmirroronline.net/news/43744.html Date Published 29 June, 2012

27. Taraba: 13 fulani herdsmen killed in fresh tribal attacks http://www.ipaidabribenaija.com/index.php/latestnews/item/4551-taraba-13-fulani-herdsmen-killed-in-fresh-tribal-attacks Date Published 12 June, 2012

28. 'Fulani herdsmen kill 75 Tiv farmers' http://www.thenationonlineng.net/2011/index.php/news/47428\%E2\%80\%98fulani-herdsmen-kill-75-tiv-farmers\%E2\%80\%99.html Date Published 22 May, 2012

29. THE MENACE OF FULANI HERDSMEN http://www.tribune.com.ng/index.php/editorial/40782-the-menaceof-fulani-herdsmen Date Published 14 May, 2012

30. Potiskum attack: Fulani herdsmen give Jonathan ultimatum

http://www.thenationonlineng.net/2011/index.php/news/45702-potisku-attack-fulani-herdsmen-givejonathan-ultimatum.html Date Published 07 May, 2012

31. Thousands of Fulani herdsmen flee Benue for C'river

http://www.channelstv.com/home/2012/03/28/thousands-of-fulani-herdsmen-flee-benue-for-criver/ Date Published 28 May, 2012

32. Influx of Fulani herdsmen worries C' River http://www.punchng.com/news/influx-of-fulani-herdsmenworries-c-river/ Date Published 28 May, 2012

33. C'River to 'repatriate' Fulani herdsmen http://www.punchng.com/news/criver-to-repatriate-fulaniherdsmen/ Date Published 29 May, 2012

34. Plateau State: Herdsmen slaughter family of $7 \mathrm{http}: / /$ pmnewsnigeria.com/2012/05/11/plateau-stateherdsmen-slaughter-family-of-7/ Date Published 11 May, 2012

35. Fulani Herdsmen Kill 13, Destroy 30 Houses In Plateau http://naijagists.com/fulani-herdsmen-kill-13destroy-30-houses-in-plateau/ Date Published 03 May, 2012

36. Herdsmen block Abuja-Jos road, waylay passengers http://www.punchng.com/news/herdsmen-block-abujajos-road-waylay-passengers/ Date Published 07 May, 2012

37. One Killed, Several Injured in Fulani-Hausa Clash In Sokoto http://saharareporters.com/news-page/onekilled-several-injured-fulani-hausa-clash-sokoto Date Published 04 April, 2012

38. Ogun pledges grazing routes, patrols to curb herdsmen's atrocities

http://www.vanguardngr.com/2012/03/ogun-pledges-grazing-routes-patrols-to-curb-herdsmens-atrocities/

Date Published 26 March, 2012 
39. Suspected Fulani herdsmen kill two policemen in Plateau state

http://www.channelstv.com/home/2012/03/21/suspected-fulani-herdsmen-kill-two-policemen-in-plateaustate/ Date Published 21 March, 2012

40. Delta villagers protest attacks by Fulani herdsmen http://www.punchng.com/news/delta-villagers-protestattacks-by-fulani-herdsmen/ Date Published 07 March, 2012

41. M-A-S-S-A-C-R-E-! Fulani herdsmen, Boko Haram kill $39 \bullet 13$ villages sacked in Benue http://www.tribune.com.ng/index.php/front-page-news/37087-m-a-s-s-a-c-r-e--fulani-herdsmen-boko-haramkill-39-13-villages-sacked-in-benue-20-feared-dead-on-akure-ilesa-expressway Date Published 06 March, 2012

42. Fulani Herdsmen Vs Ogun State Villagers At War http://www.nairaland.com/882080/fulani-herdsmen-vsogun-state/1 Date Published 29 February, 2012

43. 5000 Flee As Fulani Herdsmen Attack Benue And Nassarawa http://www.nairaland.com/815595/5000-fleefulani-herdsmen-attack Date Published 01 December, 2011

44. Herdsmen Kill 2, Molest Women In Imo http://www.nairaland.com/711381/herdsmen-kill-2-molestationwomen/6 Date Published 12 July, 2011

45. Family of 8 killed in Jos midnight attack http://www.momentng.com/en/news/3762/family-of-8-killed-injos-midnight-attack.html Date Published 05 September, 2011

46. Fulani Herdsmen And Hausa Traders Clash At Golbin Boka http://www.nairaland.com/764634/fulaniherdsmen-hausa-traders-clash Date Published 21 September, 2011

47. Birom People's Reprisal Attacks http://newsrescue.com/2011/09/birom-christians-eat-roasted-flesh-ofmuslims-they-killed-in-jos-nigeria/\#axzz203LOiZDE Date Published 29 September, 2011

48. Fulani Herdsmen kill 6 people in Plateau State

http://www.elombah.com/index.php/templates/system/css/media/system/js/news/node/index.php?option=co m_content\&view=article\&id=4321:fulani-herdsmen-kill-6-people-in-plateau-state\&catid=3:newsflash Date Published 27 October, 2010

49. Herdsmen strike in Ekiti, kill police corporal, two villagers wounded http://www.nigeriavillagesquare.com/forum/archive/index.php/t-49367.html Date Published 21 March, 2010

50. Massacre Fulani Herdsmen Kill Over 500 People In Jos WATCH https://www.youtube.com/watch?v=Gaznwma4bkI Mar 8, 2010

51. How Buhari Confronted Lam Adesina Over Death of Fulani http://www.vanguardngr.com/2012/11/day-lamadesina-clashed-with-buhari-marwa-others/

\section{HOW STRAY COWS CAUSED AIR MISHAP IN PORT HARCOURT}

http://www.iasa.com.au/folders/Safety_Issues/RiskManagement/cowcrazy.html Date Published 10 July, 2005 see also http://www.golfhotelwhiskey.com/aircraft-colliding-cows/

53. BOKO HARAM, FULANI HERDSMEN KILL 22 IN BORNO, PLATEAU

http://www.maritimefirstnewspaper.com/en/2015/12/boko-haram-fulani-herdsmen-kill-22-in-borno-plateau/ December 15, 2015

54. How Fulani herdsmen kill, rape Ogun residents, farmers https://www.linkedin.com/pulse/how-fulaniherdsmen-kill-rape-ogun-residents-farmers-osigwe-ikirodah Oct 2, 2015

55. Suspected Fulani herdsmen kill 79 in Nigeria http://www.emirates247.com/news/suspected-fulaniherdsmen-kill-79-in-nigeria-2014-04-07-1.544572 Published Monday, April 07, 2014

56. Delta: Fulani Herdsmen Kill 3, Injure 2 In Ndokwa Community http://urhobotoday.com/?p=18356 Sep 1st, 2015 State News

57. Tragedy as Fulani Herdsmen kill Palm Wine Tapper in Delta state. http://rc1023.fm/tragedy-as-fulaniherdsmen-kill-palm-wine-tapper-in-delta-state/ Dec 2, 2015

58. Sad News! Fulani Herdsmen kill Children in Plateau community (Graphic Photos)

http://www.timepostng.com/2015/09/sad-news-fulani-herdsmen-kill-children.html September 6, 2015

59. FULANI HERDSMEN KILL TWO POLICE OFFICERS IN BENUE - SAMUEL ORTOM

http://ukwubenda.com/2016/03/fulani-herdsmen-kill-two-police-officers-in-benue-samuel-ortom.html March 25,2016 
60. Muslim Fulani Herdsmen Kill 15 Christians in Plateau State, Nigeria ...Gunmen's victims include children ages 1, 3 and 5. http://morningstarnews.org/2015/12/muslim-fulani-herdsmen-kill-15-christians-in-plateau-statenigeria/ December 21, 2015

61. Police abandoned us during herdsmen invasion - Enugu community http://www.punchng.com/policeabandoned-us-during-herdsmen-invasion-enugu-community/ April 27, 2016

62. BLOODBATH: Fulani herdsmen kill 90 in Benue http://theexpressnews.com/bloodbath-fulani-herdsmen-kill90-in-benue-attack/ March 16, 2015

63. Nigeria: Two Pastors Killed in Attack by Fulani Herdsmen http://www.christianheadlines.com/blog/nigeriatwo-pastors-killed-in-attack-by-fulani-herdsmen.html October 19, 2014

64. Fulani Herdsmen Kill University Staff, Farmer in D

http://article.wn.com/view/2016/04/10/Fulani_Herdsmen_Kill_University_Staff_Farmer_in_Delta/April 10, 2016

65. Fulani herdsmen kill 12 in fresh Benue attack http://newsbreak.com.ng/2016/02/08/fulani-herdsmen-kill-

12-in-fresh-benue-attack/ February 8, 2016

66. Curfew in Taraba community as Fulani herdsmen kill 9, injure 10

http://www.newissuesmagazine.com/2016/02/curfew-in-taraba-community-as-fulani-herdsmen-kill-9-injure10/ February 27, 2016

67. Mother of three raped and killed by suspected Fulani herdsmen in Ogun

http://www.mytrinitymagazine.com/mother-three-raped-killed-suspected-fulani-herdsmen-ogun/ February 11, 2015

68. Fulani herdsmen kill 40 Tiv farmers in fresh attack on Suswam's village

http://newtelegraphonline.com/fulani-herdsmen-kill-40-tiv-farmers-fresh-attack-suswams-village/ March 8, 2016

69. Graphic Photos: Armed Fulani Herdsmen Attack Agatu LGA, Benue State, Kill Scores, Set Village Ablaze http://www.roughdiamondblog.com/2016/02/graphic-photos-armed-fulani-herdsmen-attack-agatu-lga-benuestate-kill-scores-set-village-ablaze/ February 28, 2016

70. Suspected Fulani herdsmen kill 22, sack Kogi communities http://www.newsjs.com/url.php?p=http://www.ngrguardiannews.com/2015/11/suspected-fulani-herdsmenkill-22-sack-kogi-communities/ November 12, 2015

71. Suspected Fulani Herdsmen Kill Man In Enugu http://theunion.com.ng/crime/suspected-fulani-herdsmenkill-man-in-enugu/ March 23, 2015

72. Fulani herdsmen kill DPO, others, ransack Adamawa communities http://thelightnews.com/fulani-herdsmenkill-dpo-others-ransack-adamawa-communities/ Jan 25, 2016

73. Taraba: Fulani Herdsmen Kill 44 in Fresh Attacks

http://www.thisdaylive.com/index.php/2016/04/13/taraba-fulani-herdsmen-kill-44-in-fresh-attacks/ April 13, 2016

74. APC youth leader, 3 others killed in fresh Fulani herdsmen, farmers' clash in Benue http://www.vanguardngr.com/2016/04/apc-youth-leader-3-others-killed-fresh-fulani-herdsmen-farmers-clashbenue/ APRIL 5, 2016

75. Fulani herdsmen strike again in Benue, 40 people feared dead https://www.naij.com/758853-tragic-fulaniherdsmen-strike-40-people-killed.html March 3, 2016

76. Again, Fulani Herdsmen Kill and Sack 25 Villages http://www.jolibanews.com/blog/2016/03/17/fulaniherdsmen-kill-sack-25-villages/\#.VyA5rPkrJdg MARCH 17, 2016

77. At least 205 Christians killed by Fulani Herdsmen in Nigeria, Thousands displaced, church services halted. http://www.christiantoday.com.au/article/at.least.205.christians.killed.by.fulani.herdsmen.in.nigeria/16655.htm 18 December 2013

78. Suspected Fulani herdsmen 'kill 20, including a senior policeman' in Nigeria's Adamawa state https://twitter.com/bbcafrica/status/691576881452339200 25 Jan 2016

79. Kogi Crisis: Fulani Herdsmen Kill 5 in Abugi Community http://www.kwaranews.com/kogi-crisis-fulaniherdsmen-kill-5-in-abugi-community/ Dec 22014

80. Suspected Fulani Herdsmen Kill Farmer in Enugu http://www.thetrentonline.com/suspected-fulaniherdsmen-kill-farmer-in-enugu/ Jan 16, 2016 
81. Fulani herdsmen kill 25, injure many in Nasarawa State http://thecityreporters.com/fulani-herdsmen-kill-25injure-many-in-nasarawa-state/ 10 November 2014

82. Fulani herdsmen kill 1 in Plateau http://www.newsghana.com.gh/fulani-herdsmen-kill-1-in-plateau/ May 1, 2012

83. Suspected Fulani Herdsmen Kill 8 In Kaduna http://www.channelstv.com/2015/01/28/suspected-fulaniherdsmen-kill-8-in-kaduna/ January 28, 2015

84. Community leaders lament as suspected Fulani herdsmen kill one http://guardian.ng/news/communityleaders-lament-as-suspected-fulani-herdsmen-kill-one/?ak_action=reject_mobile 09 November 2015

85. TENSION AS FULANI HERDSMEN KILL ANAMBRA FARMER AND 2 OTHERS

http://www.ireporteronline.com/23420/tension-as-fulani-herdsmen-kill-anambra-farmer-and-2-others Apr 16, 2016

86. Global Terrorism Index: Nigerian Fulani militants named as fourth deadliest terror group in world

http://www.independent.co.uk/news/world/africa/global-terrorism-index-nigerian-fulani-militants-named-asfourth-deadliest-terror-group-in-world-a6739851.html 18 November 2015 